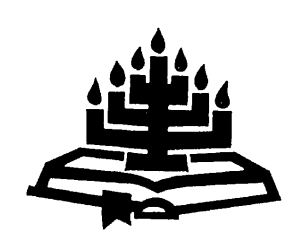

\title{
Christianisation of ancestor veneration within African traditional religions: An evaluation ${ }^{1}$
}

\author{
B. Afeke \& P. Verster \\ Department of Missiology \\ University of the Free State \\ BLOEMFONTEIN \\ E-mail: versterp.hum@mail.uovs.ac.za
}

\begin{abstract}
Christianisation of ancestor veneration within African traditional religions: An evaluation

Although Africans have welcomed the Gospel message, some African Christians have not yet abandoned the beliefs and practices of traditional religions. Ancestor veneration has been reinstated by some Africans and others try to christianise the concept. In this article an overview of different aspects of the debate on ancestor veneration is given and evaluated. The conclusion reached by the authors is that sound exegesis does not allow ancestor veneration to be tolerated in the Christian church, but that respect for ancestors should be accepted.
\end{abstract}

\section{Opsomming}

Die verchristeliking van voorouerverering in die tradisionele godsdienste van Afrika: 'n evaluering

Alhoewel die mense van Afrika die boodskap van die evangelie verwelkom het, kom gebruike en gewoontes van tradisionele godsdienste steeds voor. Sommige Afrika-Christene keer terug na die verering van voorouers terwyl ander dit probeer verchristelik. In hierdie artikel word 'n oorsig van die verskillende standpunte oor voorouerverering gegee en geëvalueer. Die outeurs kom tot die gevolgtrekking dat voorouerverering nie in die Christelike kerk aanvaar moet word nie, maar dat respek vir voorouers wel belangrik is.

1 This article is based on a mini-M.A.-dissertation of Dr. B. Afeke at the University of the Free State. 


\section{Introduction}

According to Baëta (1968:301) Africans have welcomed the message of the Gospel, but have not yet left behind beliefs and practices that for centuries have been part of the philosophy of their present existence and of life beyond the grave. Therefore, the question on how to deal with the practices of traditional religions remains relevant. Though it is a difficult question to be answered fully, African religion is not distinct from African culture and is linked to life and its activities in totality. A very important aspect of African traditional religions is their view of ancestors. Ancestor veneration is reinstated by some African Christians, while others try to christianise the concept by referring to Christ as the supreme ancestor. From this perspective the relation between Christianity and African traditional religions will be discussed.

\section{African views concerning ancestor veneration}

\subsection{The importance of ancestor veneration}

Theron (1996:45) is of the opinion that the belief in ancestors has not disappeared, and that ancestors still play an important role in the lives of African Christians. Turaki (1999:178) explains that for the greater part of sub-Saharan Africa the African community consists of the unborn living (those about to be born or in some instances about to reincarnate), the living and the living dead (those who have already died but are still remembered by the living). According to Turaki (1999:222) ancestral spirits play an important role in the African concept of man. He mentions that an ancestral spirit maintains a bond with his relatives and that by means of proper burial rites and the remembrance of the name of the ancestral spirit the state of existence in the afterlife is assured.

Mbiti (1978:152) insists that the phenomenon that Westerners call "ancestor worship" is not really worship at all. Giving food and drink to ancestral spirits is a symbol of communion, fellowship, and remembrance. The issue as to whether or not recognition of ancestors through sacrifices and offerings is reverence or worship is still relevant (Turaki, 1999:177). In this regard Mitchell (1977:5) states that ancestral spirits have the potential power to affect the living beneficially if they are respectfully and properly venerated, and adversely if their veneration is neglected. Idowu (1973:185) also explains that in some parts of Africa it is the general belief that a living mother or father, by virtue of motherhood or fatherhood, is endowed with the power effectively to bless or curse an offspring. 
This power continues after death. Food and drink must therefore be offered to ancestors (Parrinder, 1961:122).

Idowu (1973:188) describes what he captioned as "apparent reincarnation". This concept is used to explain that among certain African groups it is accepted that ancestors return in one or several children in the family. The deceased persons "reincarnate" in their grandchildren and great-grandchildren. It is believed that in spite of this "reincarnation, the deceased retain their status, and all their ancestral qualities are unimpaired. This is, however, not universally true, especially in Southern Africa.

There can, however, be no doubt that where ancestor veneration is practised, the belief that ancestors influence the daily lives of the living is present, and it is believed that as they can bring either adversity or benefit, they must either be appeased or encouraged to bless. Nyamiti (1984:16) gives evidence to this: "Although ancestors are sometimes feared, the living expect from them care and protection from sickness, death or calamities, and the acquisition of various benefits, e.g. a long life, many children or great wealth." Nyamiti (1984:16) characterises the general African concept of ancestorship by five elements:

- Natural relationships

- $\quad$ Supernatural status

- Mediation

- $\quad$ Title and regular sacred communication with earthly relatives

- Examplarity

It must be understood that in Africa ancestors are assumed to be playing an active role in the lives of the people.

\subsection{Ancestors as intermediaries}

Differences exist in Africa regarding the role of ancestors. Nyirongo's (1997:51) perspective is that ancestors act as intermediaries. Azaenya (1969:42), however, is of the opinion that they are self-sufficient and therefore receive gifts from the supreme God in order to distribute these to humans. Theron's (1996:31) view is that ancestors appear to family members in dreams or visions, or even in the forms of certain animals. Ancestors co-own property with the living. Mofokeng (quoted in Guma \& Milton, 1997:49) states that land is generally considered to be sacred, for it belongs to the earth spirit and even to the ancestors as well as to the living community. 
Therefore it is a serious offence to give away or sell property without consulting spirits and ancestors first.

In Turaki (1999:178), Gehman summarises the function of ancestors as guardians of the family's traditions and life, and rectifiers of their errors. Ancestors also serve as the owners of the land, receiving requests and offerings from the living. Gehman is of the opinion that ancestors may also serve as intermediaries between people and God. They become a source of comfort to the living. They are called the living dead because the living are conscious of their presence and they communicate with the living by revelations and other means.

\section{The christianisation of ancestor veneration}

\subsection{Christians and the practice of ancestor veneration}

With reference to Pauw and Häselbarth, Theron (1996:40) observes that in Protestant churches views regarding ancestor veneration vary from total opposition, to neutrality, to accommodation. He perceives that positive views and attempts at accommodation or adaptations mostly come from individuals within the churches. The official viewpoint of these churches is still to reject ancestor veneration, or to express negative attitudes towards it, and there is no real attempt to find an alternative. Theron is of the opinion that this attitude created a vacuum, that has been filled by Africans themselves in that a continued belief in their ancestors still exists, and in that the rites and customs of ancestor veneration are still practised in secret.

\subsection{Integrating ancestor veneration}

Bediako (1992:226) accepts the possibility of integrating ancestor veneration into Christianity. He states that an African theology of ancestors cannot be interpreted to mean that African Christianity has no further need of the Old Testament. He states that it is the Old Testament that validates such a theology of ancestors. His view is that the Old Testament presents us with the history of God's dealings in the lives of His people whose faith was not perfect, and that the Old Testament itself offers a paradigm through which to understand the similar journeying in the past. Bediako (1992:228) further observes that the lives and careers of the "Ancestors" Adam, Noah, Enoch, Abraham, Isaac, Jacob, and David - have relevance for every succeeding generation. Ancestors made 
choices, that destined traditions, and eventually these traditions merged in Christ with the history of the people of God.

Bediako (1995:228) remarks that

... [it] is such an appropriation of Scriptures, rooted in a positive theology of ancestors, which enables us to read the Gospel as having something to do with us in the present. The relevance of the Scriptures as the interpreter of the past, therefore, establishes their validity for the present. A theology of ancestors connects with an Ancestor-Christology in which Christ features as Lord among the ancestors too. In this way, the continued significance of ancestors within the life of African Christianity comes to pass through the prism of Christology, revealing in the process, the many-sided manner in which the ancestors have been part of the story of the making of Christian Africa.

Bediako (1992:224) suggests that ancestral Christology has to start with the doctrine of the communion of saints as a theological datum, a kind of fixed grid comprising a Christian answer into which the African idea must somehow be made to slot. However, the general meaning given to the phrase in use in the church does not take into account the questions that the presence of African ideas about ancestors raise for the Christian consciousness. Bediako's explanation is that the real essence of a theology of ancestors is not about the fate of the departed who were not Christians, or who were not sacramentally linked with the church. A theology of ancestors is not necessitated because many African Christians have ancestors who were not Christian. Rather, a theology of ancestors is about the interpretation of the past in a way that shows that the present experience and knowledge of the grace of God in the Gospel of Jesus Christ have been truly anticipated and pre-figured in the quest for and the response to the transcendent in former times as these have been reflected in the lives of African people (Bediako, 1992:226).

\subsection{The presence of Christ in ancestor veneration}

Du Toit (1998:56), referring to Bediako, argues that Christ has been accepted into the local African situation, not because of missionary activity, but because Christ has already been present in the situation and has called His messengers to make him manifest. Du Toit is of the opinion that African ancestor veneration has a remarkably uniform structural framework and has been well assimilated into Christology. Christ, by virtue of His incarnation, death, resurrection, 
and ascension into the realm of the spirit-power is seen as the Supreme Ancestor by some African theologians.

Mosothoane (1973:86) uses the concept of "in Christ" to explain the relation of the living dead to the church. He states: "All, both the living and the dead, are members of the body of Christ, of the church. Thus, the communion of all is found in Christ. This 'in Christ' communion is the key to Christianising the ancestor cult." Mosothoane explains that "in Christ" was the bridge over the chasm of death. For Africans this bridge is the belief in ancestors, and therefore the communion between the deceased and the family is not disrupted by death.

Mosothoane (1973:87) remarks that the Eucharist as means of communion had to be a rite into which ancestor veneration should be incorporated. The Eucharist does not only imply fellowship with Christ, but with all Christians, living and dead. African Christians should be encouraged to communicate with their ancestors within the context of the Eucharist. Provision can be made for prayers for ancestors in the Eucharist by mentioning them by name.

Mosothoane (1973:94) concludes that when the family makes sacrifices and offerings in honour of and as a symbol of fellowship with the departed ones, not only should members of the congregation be invited, but also the clergyman, to bless the animal to be slaughtered.

It is clear that this view accepts a total integration of ancestor veneration into the church.

\subsection{Jesus as supreme ancestor}

Wanamaker (1997:291) explains that ancestor Christology links an important dimension of many African Christians' identity and experience with significant aspects of Christ's function. Wanamaker begins the exposition of ancestral Christology with the family of Jesus and mentions that the starting point for an ancestral reading of the story of Jesus Christ must be the issue of Jesus' family membership. He refers to the fact that for Africans family membership is fundamentally important to the person's understanding of who he or she is.

Wanamaker (1997:292) indicates that his explanation of African Christology provides a clear biblical basis for Bishop Mogaba's declarations that for him Jesus is the supreme ancestor, but that from a Christian perspective, he must agree that Jesus is the 
greatest of all ancestors. Jesus is viewed (according to him) as greater because every other human ancestor has Jesus as his or her ancestor but only Jesus Christ has God directly as His Father (Mogaba quoted in Wanamaker, 1997:292).

Wanamaker (1997:293) continues by saying that the advocators of an ancestral theology do not deem the life and public activity of Jesus, the prophet of God, as important. According to him the reason for this view is that the quality of an individual's human existence does not play a decisive role in whether he becomes an ancestor or not. Wanamaker (1997:293) continues:

It is not unreasonable to assume, however, that for African Christians this may become an important consideration in the future as the ancestor tradition is further adapted to a Christian perspective. From an African point of view, it is also not the nature of Jesus' death, which is important. What matters is the fact of his death since from the African perspective, Jesus' death leads to his life as an ancestor.

Therefore, Christ and those who have died are united. Wanamaker (1997:293) is of the opinion that Christ's death and afterlife are assumed to be of the same character as that of all other ancestors, as the resurrection does not fit into an African worldview and does not play an important role in the acceptance of Christ as ancestor, though an African would be quite comfortable with the idea that resurrection appearances are visionary visitations of an ancestor.

In conclusion, Wanamaker (1997:294) remarks:

The major role of an ancestor is the opposite to that of bringing about misfortune to maintain good behaviour and social order. The ancestor is also a source of benefit, a giver and sustainer of the life of his descendants. Jesus after his death performs this task continuously for his living family, the church.

The providence of Christ is then placed on the same level as that of the ancestors.

\section{Biblical view of ancestor veneration}

\subsection{Biblical references}

Concerning biblical references it must be acknowledged that sound exegesis differs from a literal fundamentalistic repetition of the text. Concerning ancestor veneration certain questions must, however, be answered. It is clear that many of the explicit condemnations in 
the Old Testament are not even discussed any more, e.g. the prohibition against wearing clothes woven from different fabrics or the commandment not to charge rent. The question is then, why should the warnings against ancestor veneration not be on the same level?

The answer may lie in the fact that the religious relation with the living God is at stake here and not a ruling for the people of old. Furthermore is has to do with salvation and mediation. We are of the opinion that in Christ this mediation and salvation is complete.

The veneration of ancestors was known and practised in Old Testament times. However, the Tora and the Prophets are clearly against this practice. The Bible in Deuteronomy 18:9 warned the Israelites that when they enter the land the Lord God has given to them, they should not learn to imitate the ways of the nations there. In verse 11 it is clearly stated that the following should be avoided: the casting of spells, consulting a medium or spiritist and consulting the dead.

A similar warning is repeated in Isaiah 8:19. The people of God were again cautioned never to consult inadequate and dead sources about the future. They were forbidden to consult and seek help from the dead. The Bible's attitude to and judgement on consulting ancestor divination and a variety of occult practices are stern and fierce (Lev. 19:26; 20:27; Deut. 18:9-13; Rev. 21:8). Consulting the dead to obtain help implies divination that is disallowed by God in the Bible (NIV Discipleship Study Bible, 1988:149).

It is clear from all indications that both the Christian and African traditional religions acknowledge the existence of humans after death. However, this does not have the same meaning in both religions.

Concerning the New Testament, Ladd (1974:195) explains that the cultural background of people from Jewish and Hellenistic communities is used by Jesus and the Evangelists to explain that the righteous dead are with God, and that God will judge the world. Words like "hell" and "outer darkness" are used in connection with this judgment - but not enough evidence is provided to give a clear picture of heaven and hell. However, Jesus gave the penitent malefactor the joyous assurance "... today you will be with me in paradise" (Luke 23:43).

Paul (Ladd, 1974:553) is certain that he will be "with Christ" when he dies, but it is not totally clear what the intermediate state will be. 
There are, however, strong indications in the New Testament that the believer enters into the presence of Christ when he/she dies. Paul says that he "would prefer to be away from the body and at home with the Lord" (2 Cor. 5:8). To the Philippians Paul wrote that he had a desire to depart and to be with Christ (Phil. 1:23). In the light of 2 Corinthians 12:34, the reference to "paradise" can only be a designation of heaven. Moreover, Paul speaks of the house not made by human hands, eternal in the heavens (2 Cor. 5:1). Guthrie (1981:839) concludes that it is not possible to come any closer to Paul's idea about the intermediate state than to say that it will consist in fellowship with Christ. What is very clear is that with Paul's emphasis on Christ's lordship and mediation it is not possible to allow for any ancestor veneration in Paul's theology.

\subsection{Interpretation of biblical references}

\subsubsection{Biblical hermeneutics}

Considering the above-mentioned aspects, an exegetical and a hermeneutical evaluation should be done. Exegetically it should be taken into account that the holiness of the people of God among others should be evident in their worldview and lifestyle. Hermeunetically the issue of new views regarding inculturation and contextualization must be taken into account.

The question is whether the veneration of ancestors can be equated with taking over a cultural object from other religions for Christian purposes. Is it a cultural expression or does it change one's commitment to God?

Sanneh (1992:31) explains that in missionary work the recipient culture is the authentic destination of God's redemptive promise. He interprets the translation of the message of the Gospel as not only a necessity but also as a given reality. However, in accepting this truth we have to argue that even when Paul spoke about the unknown God of the Athenians he nevertheless did not accept any possibility of the continuing worship of the Athenian gods.

Again we would argue that if a cultural aspect changes our commitment to our one and only Saviour and Mediator this is no longer only a cultural aspect but a deeply religious one that should be avoided.

It is clear from all indications that both the Christian and the African traditional religions acknowledge life after death. According to Berkhof (1954:675) the very root of Israel's hope was founded in its 
belief in God as its Creator and Redeemer, God, as Lord of the covenant who would never fail them, because He was to them the living, the eternal, the faithful God, in whose fellowship they found joy, life, peace and perfect satisfaction. Berkhof (1954:675) explains that Israel regarded God as the one who possesses life, who transcends time and already contains within Himself a pledge of immortality. Berkhof furthermore states that humans are made for communion with God, are only a little lower than the angels, and that God has set eternity in their hearts. New views concerning the acceptance of ancestor veneration within Christianity are not consistent with the above-mentioned view.

Turaki (1999:254) is of the opinion that if ancestors act as intermediaries, they actually answer prayers and petitions directly, which is contrary to the Bible. Turaki further explains that Jesus Christ is the one and only mediator. He is the only one who can receive such prayers. If ancestors have actually become spirits, then dealing with them as spirits falls in the category of "familiar spirits". If ancestors function as intermediaries in that they receive prayers, libation, or invocation, then dealing with them becomes idolatry as they take the place of Christ who is the only mediator between God and man.

\subsubsection{The Israelite fathers}

Bediako (1992) proposes that, through Christ, African believers become the children of Abraham and the inheritors of all the Old Testament promises and of the Jewish patriarchs. In his opinion Christology opens the scriptural way for African Christians to have access to the Old Testament. The African Christian is said to have been included in the line of the Jewish ancestors through Christ; African Christians are in close fellowship with the Old Testament ancestors (saints). Similarly, through Christ, African Christians are in close fellowship with their African ancestors.

In evaluating Bediako's proposition, Turaki (1999:225) explains that the Abrahamic faith discussed in Romans 4 and Galatians 3, transcends biological birth, as it is essentially covenantal and spiritual. The implication is that Old Testament sainthood, as inherited by the New Testament saints, is not primarily a biological inheritance, but strictly a rebirth through the Abrahamic faith. Turaki rightly states that the spiritual linkage of the New Testament with the Old Testament is fundamentally covenantal, and spelt out the essential relationship between God and Israel, the people of His covenant. It is also fundamentally prophetic and Messianic, as it was 
fulfilled by Christ according to Scripture (Rom. 1:1 or 15). Thus, the Old Testament "sainthood" is deeply rooted in the Abrahamic faith (that preceded the law and the basis of the covenant).

Turaki's (1999:256) argument is correct because the cross of Christ is not a substitute for "Abrahamic faith", but a faith rooted and grounded eschatologically in the cross of Christ (Heb. 11; Rom. 4). For this reason, prior to the cross of Christ, salvation was granted by God to all those who had faith as Abraham had. The theological issue here is not having either the Abrahamic faith or faith in Christ, since both have been linked together - prophetically, eschatologically and by the Abrahamic covenant. God grants righteousness and salvation to any human being that has such active faith.

There is no doubt that the Bible accepts that the deceased are alive before God. Jesus made it perfectly clear that God is the God of the living, the God of Abraham, Isaac, and Jacob. Although it is a difficult text to understand, 1 Peter 3:19 refers to Jesus preaching to the imprisoned spirits. This is acknowledged: God is a living God and He promises eternal life to his followers and is indeed the God of Abraham, Isaac and Jacob - alive before God. It must, however, be very clear that they are not mediators and that they cannot influence the lives of people on earth other than by the example of their faith while they were still on earth.

To evaluate the possible role of ancestors within the body of Christ properly, Turaki (1999:168) asks the question: Did the ancestors have any priestly functions in accordance with Scripture? Turaki (1999:168) explains that in the Old Testament, the Israelite fathers (ancestors) were never designated as mediators and never had such functions in Israel. The ancestors never gave themselves any mediatory role, neither did the Patriarchs act as mediators or intermediaries. However, people like Enoch, Elijah and Moses did plead with God on behalf of the people but never assumed the role of living-dead mediators after their deaths so as to become ancestors who influence the living as mediators. The religious institution of the priesthood carried that role.

In the African situation, according to Turaki (1999:168), in most cases ancestors are the recipients of prayers, sacrifices and offerings from their children, the living. The traditional priests were responsible for this. At best we can say that at times ancestors acted as the messengers of the living, they visually received the African Priest of the living and passed on whatever they might have received for to the gods and divinities. This religious phenomenon 
did not exist in Israel. The Patriarchs were highly respected, but not treated in the same way as Africans treat their ancestors, e.g. as mentioned in Isaiah 63. The Patriarchs in Israel did not mediate with God for the people, as is the case in traditional Africa (Turaki, 1999:168).

\subsubsection{The implication of Jesus' death}

Another issue is the nature of Jesus' death and His resurrection. Wanamaker (1997:291-293) assumes that Christ's death was similar to that of other ancestors. The resurrection and appearance of Jesus do not fit into the African worldview, though an African would be quite comfortable with viewing the resurrection appearances as the visional visitation of an ancestor.

Looking at the nature of Christ's resurrection Berkhof (1973:346) states: "The resurrection of Christ did not consist in the mere fact that He came to life again, and that body and soul were re-united". If this were all that it involved, He could not be called "the first fruit of them that slept" (1 Cor. 15:20).

Distinct from others who were raised from the dead, Christ spoke of Himself as the resurrection and the life. He was raised by God but there is also reference to the fact that He rose through his own power.

In the light of this, Berkhof (1973:249) maintains that the resurrection of Christ had evidential value as the resurrection enters as a constitutive element into the very essence of the words of redemption, and therefore of the Gospel. Berkhof (19973:249) explains that through the resurrection Christ passed from being subject to the law. His resurrection was His entrance to a new life as the risen and exalted Head of the church and the universal Lord.

Jesus said of Himself: "I am the way, the truth and the life, no one comes to the Father but by me" (John 14:16). Peter also claimed that the work of the power of the spirit is due to the resurrection (Acts 3:11-16). The Apostle Paul stated that the preaching of the Word would be in vain if Christ had not risen (1 Cor. 15:13,14).

Christ is totally different from all others and does not fit in with the idea of a primal ancestor. The biblical language concerning Christ is of a totally different origin. If the concept of "ancestor" is used it should be totally redefined as John did with the concept of the logos. Nyamiti (1984:136) tries to adopt African traditional forms into the church by christianising shrines, the moulding of ancestral emblems, 
the introduction of African traditional prayers and ceremonies to the ancestors into Christian liturgy. It should be very clear that this is not acceptable in our view.

\section{Concluding remarks}

The fact that ancestors play an important role in the lives of Africans and that they are part of their worldview, must be acknowledged and treated with sensitivity. Opposition to and outright condemnation of ancestor veneration will simply drive it underground, as has already happened. Merely keeping quiet about it will also serve no purpose. This can give rise to the feeling that the church has nothing to say to Africans, or it can be seen as silent condonation of the veneration (Theron, 1996:49).

Though the role of the ancestors as mediators, providers and protectors must be rejected because it is forbidden by God, it should be noted that Africans have always fought against their foes and have never lost hope or courage. Nor have they been unsuccessful in their endless fight - they have survived in the midst of untold dangers, their defensive and offensive powers have been everincreasing. Many attribute this to the ancestors who, according to Africans, give them bodily strength, intellectual nobility and a degree of self-assurance. This notion should, however, be challenged as there is ample evidence that ancestor veneration has also a role to play in many of Africa's problems. Instead of looking to God in Jesus Christ many have looked to ancestors with no avail. Being a Christian, however, does not mean that a person should have no respect for ancestors and to be cut off from the community. Nevertheless it does imply taking up the cross to follow Jesus unconditionally. Therefore we suggest the following

- A theology should be put in place to inform Africans that the practice of venerating ancestors as if they have influence on people on earth and are acting as mediators is against God's commandment.

- A theology should be designed to present Jesus not just as another religious leader, but a theology that teaches that the universal application of Christ's lordship, authority and supremacy can meet all Africans' spiritual needs as enumerated above.

- Finally the deceased cannot be viewed as evil spirits who want to mislead living Christians. Biblical teaching on evil and evil spirits is explained in Ephesians 6. The influence of Christian ancestors cannot be justified from the Bible either (Theron, 1996:50). A 
positive interpretation of respect for those who have died should, however, be developed in keeping with the fifth commandment.

\section{Bibliography}

AZAENYA, A.H. 1969. God, spirits and the world. (In Dickson, K., ed. Biblical revelation and African beliefs. London : Butterworth. pp. 40-55.)

BAËTA, C.G. 1968. Christianity in tropical Africa: Studies presented and discussed at the seventh International African Seminar, University of Ghana, April 1965. Nairobi : Oxford University Press.

BEDIAKO, K. 1992. Theology and identity: the impact of culture on Christian thought in the second century and modern Africa. Oxford : Regnum Books.

BEDIAKO, K. 1995. Christianity in Africa: The renewal of a non-Western religion. Edinburgh : Edinburgh House.

BERKHOF, L. 1954. Systematic theology. Grand Rapids, Mich. : Eerdmans.

BERKHOF, L. 1973. Manual of Christian doctrine. Grand Rapids, Mich. : Eerdmans.

DU TOIT, C.W. 1998. African spirituality and the poverty of Western religious experience. Journal of Theology for Southern Africa, 100:36-60.

GUMA, M. \& MILTON, L. 1997. An African challenge to the Church in the 21st century. Cape Town : Salty Print.

GUTHRIE, D. 1981. New Testament theology. Leicester : Inter-Varsity.

IDOWU, E.B. 1973. African traditional religion. London: SCM.

LADD, G.E. 1974. A theology of the New Testament. Grand Rapids, Mich. : Eerdmans.

MBITI, J.S. 1978. The prayers of African religion. Southampton : Camelot Press.

MITCHELL, R. C. 1977. African primal religions. Niles,III. : Argus.

MOSOTHOANE, E.K. 1973. Communio Sanctorum in Africa. Missionalia, 1(2): 86-96.

NIV Disciple's Study Bible. 1988. Tennessee : Holman Bible Publishers.

NYAMITI, C. 1984. Christ as our ancestor. Harare : Mambo.

NYIRONGO, L. 1997. The Gods of Africa or the Gods of the Bible. Potchefstroom : IRS.

PARRINDER, G. 1961. West African religion. London : Epworth.

SANNEH, L. 1992. Translating the message: The missionary impact on culture. Maryknoll, NY : Orbis Books.

THERON, P. 1996. African traditional cultures and the church. Pretoria : IMER.

TURAKI, Y. 1999. Christianity and African gods. Potchefstroom : IRS.

WANAMAKER, A.C. 1997. Jesus the ancestor: reading the story of Jesus from an African Christian perspective. Scriptura, 62(3):281-298. 


\section{Key concepts:}

ancestor veneration: the phenomenon and the unacceptability of it Biblical views of ancestor veneration christianising of ancestor veneration

\section{Kernbegrippe:}

Bybelse beskouings oor voorouerverering verchristeliking van voorouerverering voorouerverering: die verskynsel en die onaanvaarbaarheid daarvan 
